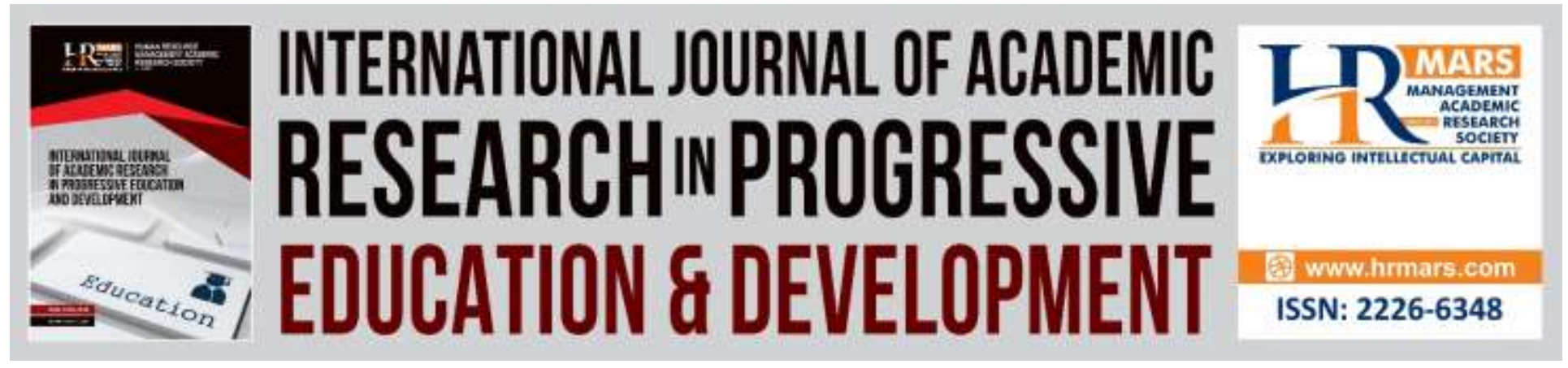

\title{
Learning Strategies Based on the Approach of Modelling by the Coach in Internalization Process of Wau Bulan Folk Dance
}

\section{Nik Md Dazpi Mustafa \& Muhammad Fazli Taib Saearani}

To Link this Article:http://dx.doi.org/10.6007/IJARPED/v8-i4/6559

DOI:10.6007/IJARPED/v8-i4/6559

Received: 21 October 2019, Revised: 10 September 2019, Accepted: 25 September 2019

Published Online: 13 November 2019

In-Text Citation: (Mustafa \& Saearani, 2019)

To Cite this Article: Mustafa, N. M. D., \& Saearani, M. F. T. (2019). Learning Strategies Based on the Approach of Modelling by the Coach in Internalization Process of Wau Bulan Folk Dance. International Journal of Academic Research in Progressive Education and Development, 8(4), 418-428.

Copyright: (c) 2019 The Author(s)

Published by Human Resource Management Academic Research Society (www.hrmars.com)

This article is published under the Creative Commons Attribution (CC BY 4.0) license. Anyone may reproduce, distribute, translate and create derivative works of this article (for both commercial and non-commercial purposes), subject to full attribution to the original publication and authors. The full terms of this license may be seen

at: http://creativecommons.org/licences/by/4.0/legalcode

Vol. 8(4) 2019, Pg. 418- 428

http://hrmars.com/index.php/pages/detail/IJARPED

JOURNAL HOMEPAGE

Full Terms \& Conditions of access and use can be found at http://hrmars.com/index.php/pages/detail/publication-ethics 


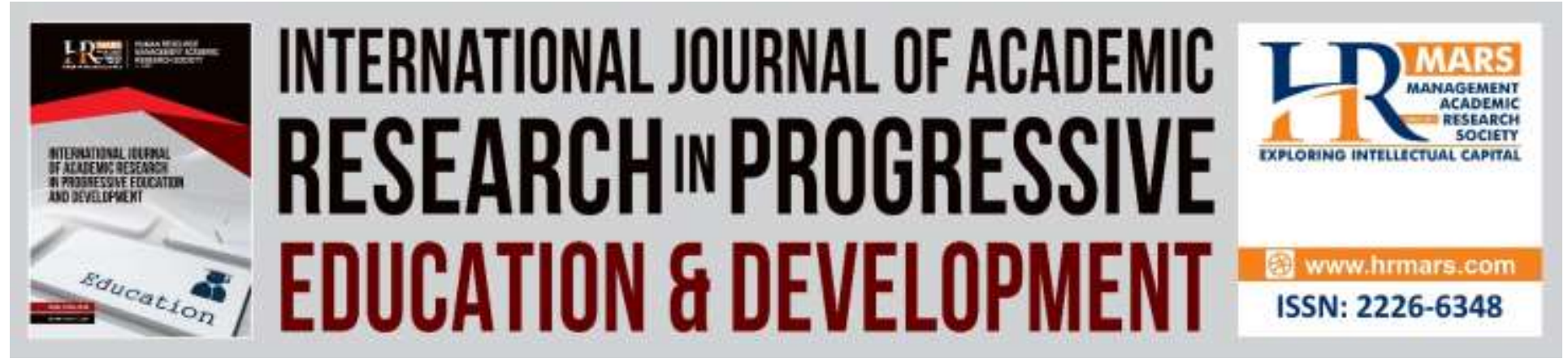

\title{
Learning Strategies Based on the Approach of Modelling by the Coach in Internalization Process of Wau Bulan Folk Dance
}

\author{
Nik Md Dazpi Mustafa \& Muhammad Fazli Taib Saearani \\ Faculty of Music and Performing Arts, Sultan Idris Education University, 35900, Tanjong Malim, \\ Perak, Malaysia \\ Email: nikdazpi@gmail.com
}

\begin{abstract}
Strategies in teaching and learning cover three key concepts consisted of approaches, methods and techniques that are interrelated and interrelated including in Malaysia Folk Dance. This research aimed to identify the systematic review on learning strategies adapted through Wau Bulan folk dance learning in general and learning strategies adapted from the modelling theory approach in dance learning through the aspects of approach. Study found that learning strategies was through general dance learning through Modelling Theory by Albert Bandura (1969) and Nana Degjana Dance (1989) approach. Both finding showed that dance approaches can focus on cognitive and psychomotor aspects at the same time. Beside, learning strategies adapted from the approach of modelling theory to dance learning based on the aspects of the approach, the researcher found that there are several teaching methods relevant to this including inductive and deductive concepts in dance teaching and learning, direct experience methods, demonstration and demonstration methods and play methods. Therefore, it is hoped that this study will help in deepening and preparing literature review related to learning strategies based on the approach of modelling by the coach in internalisation process of Wau Bulan folk dance.

Keywords: learning Strategies, Dance Approaches, General Dance Learning, Wau Bulan Folk Dance

\section{Introduction}

The historical setting of Wau Bulan dance was started from people playing Wau (Figure 1) in the rice harvest season (Asmad, 1990; Samsudin; 2011). The excitement and joy of this dance is reflected in the dance moves. The Wau Bulan dancers are made up of young men and women. The instruments used are made up of trumpets, drums, drums and gongs. In addition, the dance of Wau Bulan is a traditional dance for residents of the East Coast of Peninsular Malaysia in Kelantan. The excitement of this dance is reflected in the dance moves. According to Rahimah Ahmad (1975), in the harvest season in the state of the East Coast there are always cultural games
\end{abstract}


such as gasing, wool play, sweet potato, cardboard tambourine, wooden tambourine and others. In conjunction with the game, a dance called Wau Bulan dance was created and received a great response from the people of Kelantan. Although the beginning of every dance, dancer needs go through the process of teaching and learning.

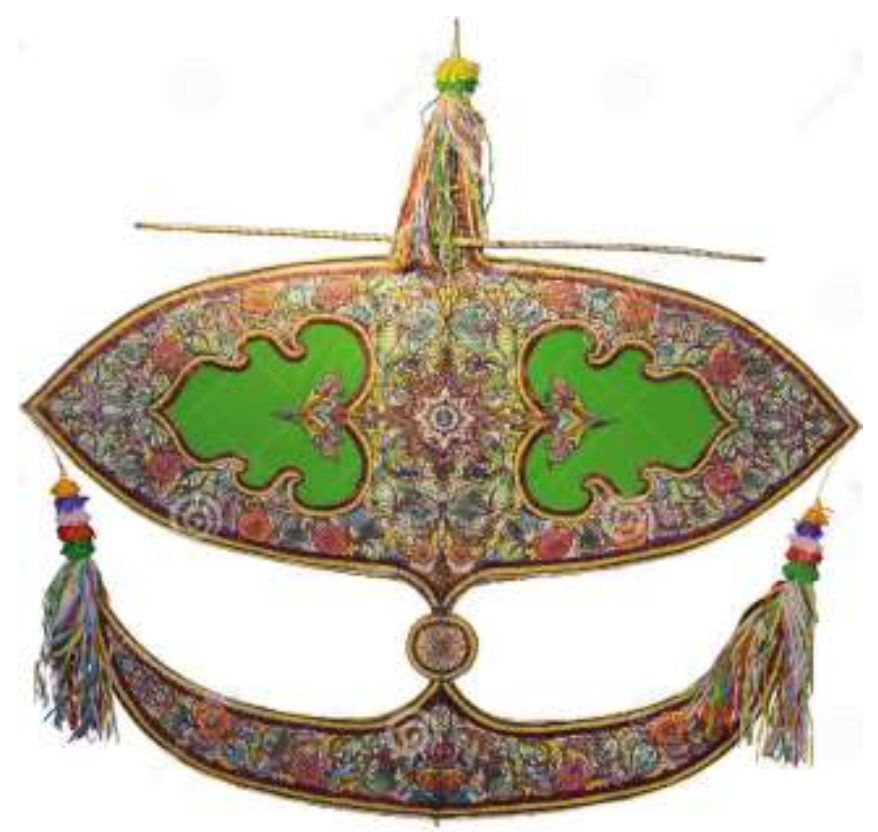

Figure 1. Wau Bulan

Through this research, researcher had founds that strategies in teaching and learning of dance cover three key concepts consisted of approaches, methods and techniques that are interrelated and interrelated. These three elements can be related to the definition of a strategy. The opinion of the researcher was also expressed by Khir (2000), expressing the concept of approaches, methods, techniques that form strategies that are related to each other and complement each other that they are difficult to be distinguish from each other. He also stated that the concept of approach, method, technique has certain characteristics. Researcher also agreed that an approach based on a particular theory, model or principle of learning is an important guide for developing appropriate methods and techniques in order to achieved internalization in dance learning.

Based on the opinions of Freiberg and Driscoll (2005), Gulo (2002), Fathurrohman (2007), and Kamus Dewan Edisi Keempat (2005), researcher concluded that their concept of strategy has the same meaning which defined strategy as one systematic planning made to achieve the objectives or goals that are expected. Systematic planning requires a specific approach to develop appropriate methods and techniques to facilitate the achievement of the goals and objectives that are expected to be achieved. Therefore, in order to achieve internalization in dance learning, a systematic strategy should be designed so that the chosen approach is a guideline to facilitate the objectives to be achieved.

According to Freiberg and Driscoll (2005), strategy is a term derived from the Greek term 'stategia' which means a plan or method of working towards a goal. In this sense, Gulo (2002), 
Syamsuddin (2001) and Fathurrohman (2007) in Maulana (2015) argued that organised strategy is an activity designed to achieve a goal. However, this definition is slightly different according to the Dictionary of the Fourth Edition of the House (2005), which states that strategies that require careful planning must have a number of appropriate and integrated approaches.

Gegene and Briggs (1980), explain that research and development strategies are defined as a teaching process by using the mind to apply models, approaches, methods and techniques to plan and implement future teaching and learning or as a guide to problem solving, finding meaning, understanding and assessment towards the achievement of the overall goals of classroom teaching and learning. The opinion of Gegene and Briggs (1980), also supported by Anthony (1963), states that the approaches involved in such learning strategies should be based on models, principles, or theories of learning. This suggests that the opinions of Gegene and Briggs (1980) and Anthony (1963), differ slightly from the concept of this learning strategy with the opinion of Razimi (2016), Shahabuddin et al. (2003) and Sang (2009), who state that the formation of this learning strategy is based on specific models, philosophies and theories of learning. However, the researchers also found that there was a consensus among the researchers that the strategy required the selection of appropriate approaches, methods and techniques in teaching and learning to achieve the targeted objectives.

According to Husin and Hajar (2011), approach is a group of interrelated assumptions about the reality of a form of teaching and learning. Sang (2011), and Noriati et al. (2009), stated that approach is a way of approaching something, namely how a subject is taught based on short- or long-term objectives. This opinion was also supported by Shahabuddin Hashim et al (2003), who stated that the teaching approach is the path or aspect used to approach or the beginning stages of the teaching process of a subject, a subject or several subjects or a skill. Contrary to the opinion of the other researchers, Husin and Hajar (2011) argued that approach is an assumption, contrary to the views of Mok Soon Sang, (2011), Noriati et al. (2009), and Shahabuddin et al. (2003), who stated that approach is the path that is used as a guide to use during the learning process. Thus, showing approach is an assumption of teacher-determined pathways during the learning process.

Opinions like Hajar (2011), Razimi (2016), Sang (2011), Noriati (2009), and Edward 1963), showed that approaches to teaching and learning were an early action in identifying a more effective teaching approach before it starts, where the teachers need to determine the most appropriate method based on the theory of learning, philosophy or model related to the goal of the teaching they want to achieve. This determination will be the guide to the next action in the research and development.

\section{Learning Strategies Adapted Through Dance Learning in General from Modelling Theory by Albert Bandura (1969)}

Mee (1997), states that Albert Bandura is an educational psychologist who proposes social learning theory. This theory emphasizes the method of modelling or learning observation in the learning process. According to Shaleh (2004) in Usman, Puluhulawa (2017), modelling is a technique that alters, enhances and reduces an individual's behavior through direct observation learning to mimic one's behavior or imitate a person's model (model) so that the individual acquires the new desired behavior. 
Vol. 8, No. 4, 2019, E-ISSN: 2226-6348 @ 2019 HRMARS

Hutomono (2011), on the other hand, states that modelling techniques are techniques aimed at learning new behaviors by observing models and studying behaviors. Kamarudin (1997), on the other hand, states that Bandura (1977) has developed a theory of social learning that proposes the concept of reciprocity. This theory shows the interaction that takes place between humans and the environment. This process of interaction causes people to constantly react to situations, and at the same time actively shape and influence the situation. According to Bandura, when learning something one is always looking for and choosing the simplest and easiest ways to do something. One of the easiest ways is to see and imitate the actions of others. In the process of learning, students are allowed to copy whatever is good to enhance their learning. According to him, imitation is one of the easiest ways for children to learn something. In the opinion of Kamarudin (2010) and Mee (1997), it can be argued that social learning theory emphasized by Albert Bandura is a theory of learning that takes place through the process of modelling, which is learning through the elements of observation and imitation. This process will result in a new behavior as a result of interacting with other people and the surrounding environment. The impersonation process of the individual and the environmental elements causes one to indicate the stimulus through behavior. This statement was also cited by Sang (2008) and Tarsono (2010), stating that there are three basic elements in this theory: individual (process), environment and behavior.

\section{Learning Strategies Adapted Through Dance Learning in General from Nana Sudjana Dance Learning Model (1989)}

Nana Sudjana Dance Learning Model (1989) focuses on three main elements of the "hear, see and do" element. The model explains how students listen to information and lessons from the coaches. Then the student will see all the processes, behaviors, facts and so on from the coach as the learning process takes place. After that, the student will repeat what the coach directs after the hearing and see what the coach is demonstrating. As such, Sudjana (1989) in Masunah and Narawati (2003), states that this model has been practiced in dance education in schools by using direct teaching methods from teachers (lectures) and demonstration methods. The lecture method used in this model is implemented when the teacher teaches and delivers the learning information directly to the pupil. Pupils are able to see, hear and act directly from the coach. While the demonstration used in this model is during the training session. The coach will practice examples of dance moves in front of the pupils who are usually behind the trainer and will practice to achieve the objectives of the teaching of mastery of spirit, spirit and spirit. As a result of the learning process, the pupils can dance well.

According to Masunah and Narawat (2003), based on the "listen, see and do" model shows that the teaching approach used is teacher-cantered teaching and it is not student-cantered. Therefore, all the knowledge, experience and skills inherent in the coach can be passed on to the student directly. This indirectly internalizes dance learning as easily transferable to students.

\section{Inductive and Deductive Concepts in Dance Teaching and Learning}

There are various opinions about deductive learning approaches. According to Shahabuddin et al. (2005), a deductive approach refers to the way of teaching that begins with the teachers providing a well-known formula or theory. According to Esah (2004), this approach is expository, 
which is that teaching begins with the definition or explanation of the characteristics of a concept. Sang (2011) points out that a deductive approach is a teaching approach that starts with one or more formulas, principles, laws, theories or rules followed by its application to specific examples. Also according to Kusinudin and Hajar (2011), teaching based on deductive thinking is a teaching approach that is based on the whole concept.

According to Kusinudin and Hajar (2011), Esah (2004), Rahil and Habibah (2009), Shahabuddin et al. (2009), and Sang (2009), the researcher can conclude that through deductive approach, a common teaching is being taught more specifically. Through this approach, the direct teaching of the teacher is very suitable to be use. All the guides will be provided by the teacher from the beginning of the lesson to the end of the lesson. In addition, through a deductive approach, the researcher can conclude that the pupil will be more guided. This approach will enable the student to understand and be able to do exactly what his teacher has instructed him to do after seeing and hearing himself easily. Learning the skills such as dance, the researcher found out that a deductive approach to dance teaching is best applied as an internalization strategy in dance.

The researchers also support the opinion of Rahil et al. (2009), in terms of deductive reasoning, teachers present students with general rules and subsequently help them identify examples and apply those rules. Therefore, through this approach to learning dance, the students will be told what they have to achieve and what they should be able to remember from previous lessons. Teachers will give oral lessons to guide student thinking. This deductive approach may be effective in solving problems because the solution begins with a step-by-step demonstration of changes in the application of a rule. Appreciation can be applied directly from the teacher or dance instructor.

This is in contrast to the inductive approach according to Shahabuddin (2005), who says that the inductive approach is an approach that gives students the opportunity to draw their own conclusions on a concept. According to Mok Soon Sang (2011), the inductive approach involves the activity of collecting and interpreting information, and then making generalizations or conclusions. According to Esah (2004), teaching that involves an inductive approach is a lesson that begins with a specific subject and then moves toward a comprehensive conclusion. Based on Hilda (1962) opinion in Esah (2004), the inductive approach is to teach something new at the beginning by giving specific examples. Then another example is added to improve student understanding. This example is provided by teachers and students. According to Hilda (1962), this approach enables pupils to be actively involved in learning.

The inductive approach based on Shahabuddin (2005) opinion, Sang (2011) and Esah (2004), gives a very similar understanding. Inductive approaches involve learning that is more student-cantered. At the beginning, the teacher only gives specific examples so that the students are finally able to draw conclusions about what the teacher is trying to convey. This approach is more about the inner approach of the student itself and more on the thinking of the high. Through this approach, students are able to learn on their own and teachers only monitor or give advice to prevent students from making false or inaccurate conclusions. Therefore, based on both approaches, deductive and inductive approaches, researchers have found that they have their own functions and roles as facilitators in teaching and learning. From the various points of view and explanations of these two concepts, researchers have found that deductive approaches 
are approaches that can be applied as complementary to internalization strategies in dance learning for primary school students. This is because the deductive approach allows students to teach more complexly.

An explanation and instruction from a teacher or coach directly allows internalization in dance teaching to make a better impact. Beginning at an early age, students are guided by the exposition of aesthetic values and then applied to the teaching of identity movements that enable students to understand and perform dance moves with appreciation. The deductive approach affects the internalization of dance learning because the in-depth explanations and instruction provided by the teacher make it easier for students to understand and appreciate better than the pupils themselves learning the aesthetics and movement of the dance.

The researcher also supported the statement of Kamarudin and Hajar (2004), who describes teaching through this approach requires that teachers understand the overall idea of the teaching and learning process. This understanding is deeply rooted in the process of transmission between teacher and student. A deductive approach is initiated by explaining, defining concepts or initiating generalizations, ideas, philosophies, or theories before they can all be analysed. Paul (1979) dedicates a deductive model such as Figure 2 below.

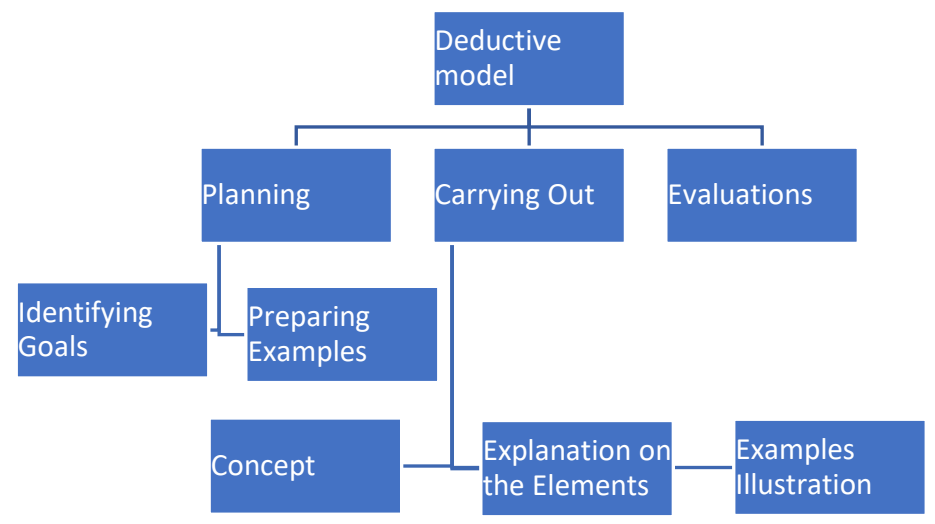

Figure 2. Deductive Model of Paul D. Eggen (1979).

In the deductive module as in Fig. 1, there are 4 stages discussed. The first is the activity planning stage. In planning, a teacher must identify the goals he or she wants to achieve. Then, through experience and knowledge, teachers will provide appropriate and sufficient examples. Teachers should also try to structure the content well. This can help teachers explain generalizations early in the lesson. Careful and thorough planning can often help facilitate student learning. The second stage is to carry out activities. Teachers will begin the process of teaching and learning by prioritizing generalization first. Generalizations such as definitions, concepts or theories, problems, rules related to learning. Generalizations should be simplified and conveyed in the clearest form. Students' understanding of learning is very important because it enables them to continue learning in a more effective way. In the final stages of learning, students' understanding will be determined through the process of trying to generalize, 
Application of those aspects of learning can reflect the degree of understanding of the student. The third stage is to evaluate the activities. This stage involves the process of looking back on the effectiveness of the teaching that has been delivered. The information gathered from the assessment results enables the teacher to determine the strengths and weaknesses of the teaching approach. If there are weaknesses in the approach, teachers will make adjustments and find ways to overcome them. Furthermore, based on dance learning researchers also agree with the model of dance learning developed by Sudjana (1989) researchers found that this model emphasized more on the deductive approach to dance learning. Emphasis on the "listening, seeing and reproducing" in dance learning has become an integral part of the school's action in learning dance: Emphasis (1) listening, refers to the activity of students listening to information and instructional materials from teachers, (2) viewing, emphasizing to student activities looking at the various processes, behaviors, facts that have been demonstrated by the teacher using the teaching materials, (3) reproducing, emphasizing student activities by repeating the tasks assigned by the teacher and the teaching materials used by the teacher (Masunah \& Narawati, 2003).

This model, which involves direct teaching from teachers, allows students to hear, see and do directly what their teacher is doing. This demonstrates that deductive learning is indeed a more effective approach to dance learning for primary school children, especially in the pursuit of the element of appreciation in dance.

\section{Direct Experience Method}

Razali, (1997), states that direct experience describes a direct learning process. It gives you the experience to see, hear, hold, feel and smell something directly. Researchers think that through direct learning from experienced teachers or coaches, the transmission of such experiences can be provided to students directly. By imitating, listening, seeing and re-doing what the teacher does, it facilitates the internalization of the dance learning process. That is, by imitating the experience of the teacher, the process of appreciating the dance by the pupils is easy.

\section{Demonstration and Instructional Methods}

Dick \& Carey (1996) in Wahi Sanusi (2010), demonstration is a way in which teachers present something to students or groups of students and demonstration methods provide an opportunity for students to make their own observations. Demonstration method according to Esah Sulaiman (2004), is a method used in teaching to show in depth how a procedure or procedure is performed and steps are performed. According to her, this method is useful in teaching skills as it is more teacher-cantered, though this method takes time to be prepare.

Shahabuddin et al. (2009) state that teaching techniques of demonstration and demonstration are used by teachers when conducting lessons that require students to develop a skill first before the actual activity. According to Meng (2003), demonstrations and demonstrations are a way of teaching where an individual does something in front of others to show how an act is done. Demonstrate the use of forms of communication, hearing and vision. Therefore, demonstration or demonstration method is a very similar method that can be used in teaching and learning. The same is true of dance teaching and learning. Effectiveness in mastering dance skills is essential to demonstration and demonstration methods. 
Vol. 8, No. 4, 2019, E-ISSN: 2226-6348 @ 2019 HRMARS

This method can explain an aesthetic value of dance directly and enable students to acquire knowledge quickly and easily. It also allows dance movements to be taught individually according to certain rules. Appreciation through this method can be absorbed into students. As a result of the demonstration the students were able to dance and appreciate a dance taught more effectively. The experience and skills of a coach can be shared and passed on to his students through this method. This sharing makes the method of appreciation easy.

\section{Playing Methods}

Friedrich Froebel in Shahabuddin et al. (2009) stated that playing is the highest expression of human development in childhood. This statement was also supported by Jacqueline (1976). In the study of Smith (1976), it was argued that early stimulation through play for children should be used as an alternative to motivating primary school children to engage and engage in dance. In fact, according to Juju and Tati (2003) that agrees with the opinion of Jacqueline (1976), who stated that play was an early stimulus to motivate primary school students to become interested and engaged in dance. This free expression or expression is contained in the spirit of a child. Juju and Tati (2003), also emphasized the importance of play in influencing the development of physical and verbal skills, music and self-expression in early childhood education. Studies have shown that play is an important determinant of personality development, creativity, emotional stability, social and intellectual development.

Based on these discussions, the researcher found that besides the demonstration and demonstration methods discussed, play was also important as an alternative or early stimulus to dance appreciation, especially for elementary school students. Researcher stated this based on the study of Jacqueline Smith (1976) in Juju and Tati (2003), early stimulation should be used as an alternative to motivating primary school students to engage in dance. Playing methods can be applied to motivate students to appreciate the dance they learn. In addition, Rost and De Gross in Juju and Tati (2003), also emphasized that games for children can have a positive impact as they develop psychomotor, cognitive, affective, creative, motivational and emotional to children's developmental processes. Therefore, researchers think that students will appreciate it more when they have experience than the game elements they understand. Demonstration methods and methods of play can be complemented by internalization strategies in dance education in primary school. This is because through the game it allows for an invention of experiences created from the initial stimulus to primary school students. This experience facilitates the process of internalization for students especially in the creation of a dance. Demonstration methods from experienced and experienced coaches make it easier for students to appreciate and understand the dance they learn. Researchers have found this method to complement the strategies of internalization in dance learning in primary school students.

\section{Conclusion}

This study has focused on the need for researching on the learning strategies adapted through dance learning in general and the focus of research on learning strategies adapted through the modelling theory approach in dance learning through the aspects of approach. For the literature review on the study of learning strategies adapted through general dance learning, the researchers found that the approach by Modelling Theory by Bandura (1969) and Dance (1989) 
showed that dance approaches can focus on cognitive and psychomotor aspects at the same time. However, for the literature review for the learning strategies adapted from the approach of modelling theory to dance learning based on the aspects of the approach, the researcher found that there are several teaching methods that are relevant to this. These methods include inductive and deductive concepts in dance teaching and learning, direct experience methods, demonstration and demonstration methods and play methods. Therefore, it is hoped that this study will help in deepening and preparing literature review related to learning strategies based on the approach of modelling especially using Modelling Theory by Bandura (1969) and Dance (1989) in internalisation process of folk dance in Malaysia.

\section{References}

Asmad. (1990). Siri bunga rampai kebudayaan Malaysia: Kesenian tari. Melaka: Associated Educational Distrubutors (M) Sdn. Bhd.

Dagang, M. (2015). Strategi pembelajaran seni budaya pada bidang seni muzik di SMA N 1 Sleman. Yogyakarta: Universiti Negeri Yogyakarta.

Edward, M. A. (1963). Approach, method, and technique. ELT Journal, 8(2), 63-67,

Ee, A. M. (1990). Pedagogi satu pendekatan bersepadu. Petaling Jaya: Penerbit Fajar Bakti Sdn. Bhd.

Esah, S. (2004). Pengenalan Pedagogi. Skudai, Johor: Universiti Teknologi Malaysia.

Freiberg, H. J. \& Driscoll, A. (2005). Universal teaching strategies. Boston: Pearson Education, Inc.

Gegene, R. M. \& Briggs, L. J. (1980). Principles of instructional design. New York: Holt, Rinehart and Winston. Inc.

Gulo, W. (2002). Strategi belajar mengajar. Jakarta: Gramedia Widiasarana.

Hutomono, S. (2011). Observasional learning: Metode psikologis yang dilupakan dalam psikologi olahraga. Jurnal IImiah SPIRIT, 11(1), 1-12

Jacqueline, M. S. (2013). The art of dance in education. London, New Delhi, New York, Sydney: Bloombury.

Juju, M. \& Tati, N. (2003). Seni dan pendidikan: Seni sebuah Bunga Rampai. Bandung, Indonesia: Pusat Penelitian dan Pembangunan.

Kamarudin, H. \& Hajar, S. A. A. (2011). Pedagogi asas pendidikan. Selangor: Kayazano Enterprise. Kamarudin, H. (1988). Pedagogi Bahasa Melayu. Kuala Lumpur: Logman (M).

Kamarudin, H. (1997). Psikologi bilik darjah: Asas pedagogi. Kuala Lumpur: Utusan Publication \& Distributors Sdn. Bhd.

Kamarudin, H. (2010). Psikologi pembelajaran. Kuala Lumpur: Utusan Publication \& Distributors Sdn. Bhd.

Kamus Dewan Edisi Keempat. (2005). Kamus Dewan Edisi. $\left(4^{\text {th }}\right)$. Kuala Lumpur: Dewan Bahasa dan Pustaka.

Lee, S. M. (1997). Psikologi Pendidikan 2: Teori dan aplikasi psikologi dalam pengajaran dan pembelajaran. Selangor Darul Ehsan: Kumpulan Budiman Sdn. Bhd.

Mok, S. S. (2008). Psikologi pendidikan dan pedagogi: Murid dan alam belajar. Selangor: Penerbit Multimedia Sdn. Bhd.

Mok, S. S. (2009). Teks Komprehensif PTK: Pengajaran \& pembelajaran (P\&P). Puchong, Selangor: Penerbit Multimedia Sdn. Bhd. 
INTERNATIONAL JOURNAL OF ACADEMIC RESEARCH IN PROGRESSIVE EDUCATION AND DEVELOPMENT

Vol. 8, No. 4, 2019, E-ISSN: 2226-6348 @ 2019 HRMARS

Mok, S. S. (2011). Pedagogi untuk pengajaran dan pembelajaraan. Selangor Darul Ehsan: Penerbit Multimedia Sdn. Bhd.

Noriati, R. (2009). Murid dan alam belajar. Shah Alam: Oxford Fajar.

Rahil, M. \& Habibah, E. (2009). Amalan pengajaran berkesan. Selangor Darul Ehsan: Karisma Publication Sdn. Bhd.

Rahimah, A. (1975). Tari-Tarian Malaysia. Kuala Lumpur: Kementerian Kebudayaan, Belia Dan Sukan Malaysia.

Samsudin, H. (2011). Siri tarian dan alat muzik tradisonal 1 Malaysia: Tarian tradisional rakyat. Kuala Terengganu: Samudera Didik.

Shahabuddin, H. \& Rohizani, Y. (2003). Pedagogi: Strategi dan teknik mengajar dengan berkesan. Pahang: PTS Publications \& Distributor Sdn. Bhd.

Shahabuddin, H., Rohizani, Y. \& Zohir, A. (2009). Pedagogi: Strategi dan teknik mengajar dengan berkesan. Selangor: PTS Publications \& Distributor Sdn. Bhd.

Shahabuddin, H. (2005). Pedagogi strategi dan teknik mengajar berkesan. Kuala Lumpur: PTS Publications \& Distributor Sdn. Bhd.

Shahabuddin, H. (2003). Psikologi pendidikan. Bentong: PTS Publications \& Distributor Sdn. Bhd.

Sulaiman, N. R. (1997). Pedagogi: Teori dan praktik. Selangor: Dewan Bahasa dan Pustaka.

Syamsuddin, M. (2001). Psikologi kependidikan perangkat sistem pengajaran modul. Bandung, Indonesia: PT Remaja Rosdarkarya.

Tarsono. (2010). Implikasi Teori Belajar Sosial (Social Learning Theory) dari Albert Bandura Dalam Bimbingan Konseling. Psympathic, Jurnal IImiah Psikologi, 3(1), 29-36.

Usman, P. S. (2017). Teknik modelling simbolis dalam layanan bimbingan dan konseling. Proceeding Seminar dan Lokakarya Nasional Revitalisasi Laboratorium dan Jurnal IImiah dalam Implementasi Kurikulum Bimbingan dan Konseling Berbasis Kkni, 4 - 6 Agustus 2017, Malang, Jawa Timur, Indonesia 